\title{
SLC7A2 wt Allele
}

National Cancer Institute

\section{Source}

National Cancer Institute. SLC7A2 wt Allele. NCI Thesaurus. Code C119687.

Human SLC7A2 wild-type allele is located in the vicinity of $8 p 22$ and is approximately 73 $\mathrm{kb}$ in length. This allele, which encodes cationic amino acid transporter 2, plays a role in amino acid transport. 